\title{
HLA-B27 antigen frequency among suspected Spondyloarthropathy patients attaining a tertiary level hospital of Bangladesh
}

\author{
Nessa A, Tabassum S, Sultana S \\ Tissue Typing Laboratory, Dept. of Virology, Bangabandhu Sheikh Mujib Medical University, Dhaka. \\ Email: afzalunnessa@yahoo.com
}

\begin{abstract}
Human leukocyte antigen B27 (HLA-B27), a class I molecules of the major histocompatibility complex has a strong disease association with different types of spondarthropathies (SpA). The strength of this disease association varies markedly among racial and ethnic populations. The present study aimed to identify the HLA-B27 antigen frequencies among suspected SpA patients as well as healthy Bangladeshi individuals. The frequency of HLA-B27 was determined in 1500 patients and 1000 healthy subjects attending the Bangabandhu Sheikh Mujib Medical University (BSMMU). HLAB 27 typing was done by microlymphocytotoxicity test using commercial kit. A total of 738 (49.2\%) suspected SpA patients and $107(10.7 \%)$ healthy subjects tested positive for HLA-B27 antigen with higher frequency among younger age groups $(54.9 \%, 52.4 \%$ and $56.2 \%$ in $0-14$ years, 15-24 years and 25-34 years of age respectively). The male female positivity was almost same $(11.4 \%$ and $9.6 \%)$ among control group, but in patient group it was $53.0 \%$ and $41.2 \%$ respectively. The findings of this hospital based study showed a high frequency of HLA-B27 among suspected SpA patients with male preponderance which is comparable with neighboring countries.
\end{abstract}

\section{Introduction}

Human leukocyte antigens (HLA) class I, are a group of glycoprotein found on the surface membrane of leukocytes and other nucleated cells. HLA plays a key role in immune responses such as antigen presentation and recognition of selfpeptides and non-self peptides as these responses affect the $\mathrm{T}$-cell receptors and coordination of cellular and humoral immunity. These are the inherited gene markers encoded by the major histocompatibility complex (MHC) molecules located on the short arm of chromosome 6 . One of the strongest linkages known to date between the presence of HLA allele and disease susceptibility is that of HLA-B27 to inflammatory SpA which was first recognized in 1973. ${ }^{1,2} \mathrm{SpAs}$ are multifactorial diseases that constitute a cluster of interrelated overlapping chronic inflammatory rheumatic diseases, such as reactive arthritis $(\operatorname{Re} A)$, psoriatic arthritis (PsA), enteropathic arthritis, a subgroup of juvenile chronic arthritis, ankylosing spondylitis (AS), and undifferentiated spondyloarthropathy (USpA). They seem to have an immune-mediated pathogenesis that share a number of clinical, radiographic, and genetic characteristics with a well-defined group of rheumatic disorders. ${ }^{3}$ Association of HLA-B27 with the entire group of spondyloarthropathies is well known and its association varies markedly among different forms of $\mathrm{SpA}$ and among different ethnic populations. ${ }^{4}$

Initial observations of the association of HLA-B27 with ankylosing spondylitis (AS), a prototype of SpA were made among Caucasians from Europe and North America. ${ }^{2}$ Subsequent studies have established the presence of HLA-B27 in AS patients in almost every ethnic group, including Japanese, Chinese, Native Americans, Brazilians, Mexicans, African-Americans, Asian Indians, Iranians, Iraqis, Israelis, Lebanese, and Alaskan and Siberian Eskimos. ${ }^{5-15}$ However, the prevalence of HLA-B27 varies among populations and ethnic groups worldwide. For example, about $8 \%$ of Caucasians, $4 \%$ of North Africans, 2-9\% of Chinese and $0.1-0.5 \%$ of Japanese descent possess this gene. ${ }^{16}$ Molecular studies have revealed at least 31 HLA-B27 subtypes with various distributions in different populations. ${ }^{17-20}$ These subtypes differ by one or more amino acid substitutions in the antigenic peptide-binding groove. $^{21}$

Population-specific distribution of HLA alleles is necessary both in population genetics and in HLA disease association studies. Anthropological studies show that the distribution of HLA alleles differ from one ethnic group to another. The genetic 
background of Bangladeshi people appears to be a mixture of different populations, mainly including Indo-Aryan, Austro-Asiatic, Dravidian, Mughal, Arab, Persian, Turkic and British. ${ }^{22}$ Although there has been a steady flow of publications describing the geographical prevalence of HLA-B27 and the frequency and distribution of its subtypes in different populations and ethnic groups, to our knowledge there is no published report on HLAB27 distribution among the Bangladeshi populations. Therefore, the aim of this study was to investigate the frequency of HLA-B27 antigen among suspected SpAs patients as well as healthy people of Bangladesh.

\section{Materials and Methods}

A total of 2500 subjects-1500 suspected Spondyloarthropathies (SpA) patients and 1000 healthy organ donors referred to the Tissue Typing Laboratory of the Department of Virology, BSMMU for HLA-B27 typing and HLA- A, B and DR typing respectively, from January 2010 to June 2013 were enrolled in this prospective study as patient and control group. Relevant information was collected from the patient's record register. Owing to the lack of validation of modified New York criteria $^{23}$ or the new ASAS (Assessment of Spondylo Arthritis International Society)

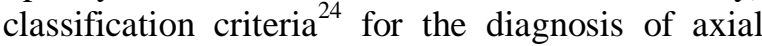
and peripheral SpA, subjects presenting with SpA related clinical manifestation, such as, low back pain with morning stiffness, buttock pain, enthesitis, peripheral arthritis, etc., were chosen as suspected SpA cases. Relevant data of control groups were collected from the laboratory record register of bone marrow and kidney donors tested at this laboratory at the same time frame. Donors who had history of chronic arthritis or $\mathrm{SpA}$ related complaints were excluded from the control group. All cases from both study and control groups were Bangladeshi in origin. The age distribution of the patients was not normal distribution. For data analysis, patients were divided into five age groups at 10 years of age interval. First and last age groups were considered as $<14$ yrs and $>45$ yrs as sample size was less among these two groups.

HLA Typing: The laboratory test was performed according to the microlymphocytotoxicity technique of Terasaki and McClelland. ${ }^{25}$ The basis of this procedure is specific antibody mediated cytolysis in the presence of complement. This is a modified National Institute of Health (NIH) microlymphocytotoxicity method ${ }^{26}$ that employs a sensitization step of cells (antigen) with serum (antibody) and the second stage is the specificity step achieved by addition of rabbit complement. In this method, freshly isolated lymphocytes from heparinised blood are incubated with a panel of known HLA-anti-sera present in Terasaki Typing Tray. After incubation, rabbit complement is added in each test well. Then the complement mediated cell lysis of the test positive well is visualized by dye exclusion method and interpreted under inverted microscope. In this study, Lymphocytes were isolated from $5 \mathrm{cc}$ of fresh heparinized venous blood by Ficoll-Hypaque (Sigma diagnostic, USA) density gradient centrifugation technique and HLAB27 Typing Tray with pre-dropped anti-sera and controls for HLA-B27 (ONE-LAMBDA INC, 21001 Kittridge st Canoga Park, CA 91303 U.S.A.) was used.

Statistical Analysis: Statistical analysis was carried out using SPSS 17.0 software. Chi-square test was used to compare HLA-B27 frequencies among patient and control groups. The confidence interval (CI) of the calculated odds ratio (OR) was estimated by approximate $95 \%$. Results were considered significant when the $p$-value was less than 0.05 .

\section{Results}

Demographic data of study and control groups are shown in Table I. The mean age of the patients was $30 \pm 10.2$ years with lowest age 7 and highest 65 years of age. Maximum numbers (37.1\%) of patients were within 25-34 years of age. HLA-B27 antigen was detected in $739(49.3 \%)$ out of the 1500 patients, whereas, among the 1000 control subjects, only 107 (10.7\%) had HLA-B27 antigen (Table II). Among the study group, 1014 (67.6\%) were males and $486(32.2 \%)$ were females. The distribution of HLA-B27 positivity among males and females were $539(53.0 \%)$ and $200(41.2 \%)$ among patients, and $69(11.4 \%)$ and $38(9.6 \%)$ respectively among control group. No significance of difference in HLA-B27 positivity was encountered among males and females of control group but in the patient group, it was significantly higher among males $(\mathrm{p}<0.001)$ (Table III). Among different age group of patients, the frequency was found to be $54.9 \%, 52.4 \%$ and $56.2 \%$ in the $0-14$ years, 15-24 years and 25-34 years age groups respectively and then gradually decreased with the increase of age, and was $40.3 \%$ in $35-44$ years and $30.0 \%$ among patients more than 45 years of age. There was no significant difference of B27 positivity within younger age groups, but when compared with older B27 positive subjects, this difference was highly significant $\quad(p<0.001)$ (Table IV). 
Table I: Demographic data of study groups.

\begin{tabular}{ccc}
\hline Characteristics & $\begin{array}{c}\text { Patients Group } \\
(\mathrm{n}-1500)\end{array}$ & $\begin{array}{c}\text { Control Group } \\
(\mathrm{n}-1000)\end{array}$ \\
\hline $\begin{array}{c}\text { Mean Age }( \pm \mathrm{SD}) \\
\text { (in years) }\end{array}$ & $31(30 \pm 10.2)$ & $35(34 \pm 9.5)$ \\
Sex (F/M) & $486 / 1014(1: 2.09)$ & $396 / 604(1: 1.53)$ \\
\hline
\end{tabular}

Table II: Frequency of HLA-B27 among suspected SpA patients and healthy controls.

\begin{tabular}{ccccc}
\hline HLA-B27 & $\begin{array}{c}\text { SpA Patients } \\
(\mathrm{n}-1500)\end{array}$ & $\begin{array}{c}\text { Control } \\
(\mathrm{n}-1000)\end{array}$ & $\begin{array}{c}\text { Total } \\
(\mathrm{n}-2500)\end{array}$ & Significance \\
\hline Positive & 739 & 107 & 846 & \\
& $(49.3 \%)$ & $(10.7 \%)$ & $(33.84 \%)$ & $\mathrm{P}<0.001$ \\
Negative & 761 & 893 & 1654 & \\
& $(50.7 \%)$ & $(89.3 \%)$ & $(66.16 \%)$ & \\
\hline
\end{tabular}

Table III: HLA-B27 frequency among SpA Patients and control groups according to gender.

\begin{tabular}{|c|c|c|c|c|c|c|c|c|}
\hline \multirow{2}{*}{$\begin{array}{l}\text { HLA- } \\
\text { B27 }\end{array}$} & \multicolumn{4}{|c|}{ SpA Patients (n- 1500) } & \multicolumn{4}{|c|}{ Control (n-1000) } \\
\hline & $\begin{array}{c}\text { Male } \\
(\%)\end{array}$ & $\begin{array}{c}\text { Female } \\
(\%)\end{array}$ & $\begin{array}{c}\text { Total } \\
(\%)\end{array}$ & $\begin{array}{l}\text { Signifi- } \\
\text { cance }\end{array}$ & $\begin{array}{c}\text { Male } \\
(\%)\end{array}$ & $\begin{array}{c}\text { Female } \\
(\%)\end{array}$ & Total & $\begin{array}{l}\text { Signifi- } \\
\text { cance }\end{array}$ \\
\hline Positive & $\begin{array}{c}539 \\
(53.0)\end{array}$ & $\begin{array}{c}200 \\
(41.2)\end{array}$ & $\begin{array}{c}739 \\
(49.3)\end{array}$ & & $\begin{array}{c}69 \\
(11.4)\end{array}$ & $\begin{array}{c}38 \\
(9.6)\end{array}$ & $\begin{array}{c}107 \\
(10.7)\end{array}$ & \\
\hline Negative & $\begin{array}{c}475 \\
(47.0)\end{array}$ & $\begin{array}{c}286 \\
(58.8)\end{array}$ & $\begin{array}{c}761 \\
(50.7)\end{array}$ & & $\begin{array}{c}535 \\
(88.6)\end{array}$ & $\begin{array}{c}358 \\
(87.9)\end{array}$ & $\begin{array}{c}893 \\
(89.3)\end{array}$ & \\
\hline Total & $\begin{array}{r}1014 \\
(67.6) \\
\end{array}$ & $\begin{array}{r}486 \\
(32.4) \\
\end{array}$ & $\begin{array}{l}1500 \\
(100)\end{array}$ & $P<0.05$ & $\begin{array}{r}604 \\
(60.4) \\
\end{array}$ & $\begin{array}{r}396 \\
(39.6) \\
\end{array}$ & $\begin{array}{l}1000 \\
(100) \\
\end{array}$ & $P>0.10$ \\
\hline
\end{tabular}

Table IV: Distribution of HLA-B27 among different age groups of suspected SpA patients.

\begin{tabular}{lcccc}
\hline $\begin{array}{l}\text { Age Group } \\
(\mathrm{yrs})\end{array}$ & $\begin{array}{c}\text { Positive } \\
(\%)\end{array}$ & $\begin{array}{c}\text { Negative } \\
(\%)\end{array}$ & Total & Significance \\
\hline $0-14$ & 39 & 32 & 71 & \\
$(\mathrm{n}-71)$ & $(54.9)$ & $(45.1)$ & & \\
$15-24$ & 202 & 183 & 385 & \\
$(\mathrm{n}-385)$ & $(52.4)$ & $(47.6)$ & & \\
$25-34$ & 313 & 244 & 557 & $\mathrm{P}<0.001$ \\
$(\mathrm{n}-557)$ & $(56.2)$ & $(43.8)$ & & \\
$35-44$ & 152 & 225 & 377 & \\
$(\mathrm{n}-377)$ & $(40.3)$ & $(59.7)$ & & \\
$>45$ & 33 & 77 & 110 & \\
$(\mathrm{n}-110)$ & $(30.0)$ & $(77.0)$ & & \\
Total & 739 & 761 & 1500 & \\
$(\mathrm{n}-1500)$ & $(49.3)$ & $(50.7)$ & & \\
\hline
\end{tabular}

\section{Discussion}

The human leukocyte antigen HLA-B27 is strongly associated with development of a group of inflammatory arthritis collectively known as the spondyloarthropathies that include ankylosing spondylitis (AS), psoriatic arthritis, reactive arthritis and arthritis with inflammatory bowel disease $^{1,2}$ and this association was first recognized in 1973. Since then, a great amount of scientific research has been performed on HLA-B27 worldwide, but in Bangladesh, little is known regarding HLA-B27 prevalence and its relation with SpAs. To the best of our knowledge, the present study is the first of its kind among Bangladeshi people.

The prevalence of HLA-B27 among healthy individuals vary greatly in different ethnicities ranging from $0 \%$ in African Bantu and Australian Aborigines to $50 \%$ in Native Americans. ${ }^{27}$ It was found to be $18-50 \%$ in American Indians, 10-16\% in Scandinavians, 6-9\% in Western Europe, 2-6\% in Southern Europe, 6-8\% in Pakistanis, 2-6\% in Indians, $1 \%$ in Japanese, and $1 \%$ in Africans. ${ }^{27,28}$ Our study observed $10.7 \%$ frequency of B27 among healthy people with almost similar pattern of distribution among males (11.4\%) and females $(9.6 \%)$. This prevalence was similar to some prevalence reports from other Asian countries surrounding Bangladesh, e.g., 8.3\% from West India $^{29}$ and $1.7 \%$ from Mumbai, ${ }^{30} 12.5 \%$ from Punjab, $1.3 \%$ from Sindh and $7.2 \%$ from Urdu speaking people of Pakistan. ${ }^{31}$ Low frequency in Mumbai of India and Sindh of Pakistan may be due to ethnic variations of their origin.

The degree of association between HLA-B27 and spondyloarthropathies ( $\mathrm{SpA}$ ) vary markedly among different diseases of this group and also between different populations. Ankylosing spondylitis (AS) is the most common subtype of SpA and exhibits the strongest association with HLA-B27. About 95\% of the Caucasian AS patients express HLAB27, ${ }^{32}$ while only $50 \%$ of African American patients with ankylosing spondylitis possess HLAB27 antigen. ${ }^{33}$ In our study, out of 1500 patients $739(49.3 \%)$ were HLA B-27-positive with the maximum numbers of patients (942 out of 1500) within 15 to 34 years of age. The HLA-B27 positivity was found to be high among this age range $52.4 \%$ in $15-24$ years and $56.2 \%$ in $25-34$ years of age). It then gradually decreased with the increase of age, and at $>45$ years age group, it decreased to $30.0 \%$. This corresponds with the characteristics of AS and other SpAs, as these inflammatory disorders usually have an early age of onset while the degenerative arthritis are more likely to predominate at older age. Various studies from India show similar pattern of distribution. A study from South India reported the frequency of B27 as $46 \%$ in SpA patients, ${ }^{34}$ while a study on 110 patients with Seronegative Spondyloarthropathy (SSA)- that is SpA patients who are negative for rheumatoid factor, the overall frequency was $43.6 \%$ with a higher positivity among children (68.75\%) and in males $(81.81 \%) .{ }^{35}$ Similar findings were also reported from patients of Asian Indian origin, where frequency was 56\% among SSA patients with male predominance. ${ }^{36}$ The present study also revealed significantly higher prevalence of HLAB27 among male patients $(53.0 \%)$ than female $(41.2 \%)$.

There is a marked variation in the general prevalence of HLA-B27 in various healthy populations as well as in AS and related SpA patients of different racial and ethnic groups. Therefore, the clinical usefulness of the HLA-B27 
test in the diagnosis of AS and related SpAs differ appreciably among different populations. People with low general prevalence and strong disease association of HLA-B27 with AS and related SpAs have highest clinical usefulness of B27 test in disease diagnosis. For example, the Japanese show a strong disease association (>85\%) of HLA-B27 with AS, but the frequency of this gene in their general population is less than $1 \%{ }^{16}$ On the other hand, a positive test result will be relatively less useful among Eskimos, as because of high prevalence HLA-B27 (25\% - 40\%) among their general population. ${ }^{16}$ Our study observed that, $49.3 \%$ of the suspected SpA patients were positive for HLA-B27 and in general population, it was $10.7 \%$. However, findings of this study does not reflect the actual prevalence of HLA-B27 among confirmed AS and SpAs cases because all suspected cases presenting with any $\mathrm{SpA}$ related clinical manifestation tested for HLA-B27 at the Tissue Typing Laboratory of BSMMU were included without validation of ASAS classification criteria. Therefore, further study is needed to delineate the association of HLA-B27 antigen with confirmed $\mathrm{SpA}$ and $\mathrm{AS}$ cases and its clinical usefulness in disease diagnosis.

Conclusion: Despite the limitations our study, the findings revealed that the frequency of HLA-B27 is relatively high among Bangladeshi arthritis patients. However, many factors such as ethnic background, geographic variance, and overall environmental factors should be considered before making a definite conclusion. Further extensive studies on confirmed SpA patients are needed to assess the prevalence of HLA-B27 among different groups of spondyloarthropathies patients in Bangladesh.

\section{References}

1. Schlosstein L, Terasaki PI, Bluestone R, Pearson CM. High association of an HL-A antigen, W27, with ankylosing spondylitis. N Engl J Med 1973; 288:704-6.

2. Brewerton DA, Hart FD, Nicholls A, Caffrey M, James DCO, Sturrock RD. Ankylosing spondylitis and HLA27. Lancet 1973; 1: 904-7.

3. Khan MA. Update of Spondyloarthropathies. Ann Intern Med 2002; 136: 896-907.

4. Akkoc N, Khan MA. Epidemiology of ankylosing spondylitis and related spondyloarthropathies. In: Weisman MH, Reveille JD, vander Heijde D, eds. Ankylosing Spondylitis and the Spondyloarthropathies: A Companion to Rheumatology. London, Mosby: Elsevier; 2006: 117-31.

5. Yamaguchi A, Ogawa A, Tsuchiya N, Shiota M, Mitsui $\mathrm{H}$, Tokunaga K, et al. HLA-B27 subtypes in Japanese with seronegative spondyloarthropathies and healthy controls. J Rheumatol 1996; 23(7): 1189-93.
6. Sonozaki H, Seki H, Chang S, Okuyama M, Juji T. Human lymphocyte antigen, HL-A27, in Japanese patients with ankylosing spondylitis. Tissue Antigens 1975; 5: 131-6.

7. Zeng QY, Huang SB, Zhou XG. Population and family study of ankylosing spondylitis and clinical uses of HLA-B27 determination [Chinese]. Zhonghua Nei Ke Za Zhi 1987; 26: 387-9.

8. Zheng SQ. Ankylosing spondylitis, rheumatoid arthritis and HLA antigens in Chinese [Chinese]. Zhonghua Nei Ke Za Zhi 1983; 22: 285-7.

9. Shankarkumar U, Ghosh K, Mohanty D. HLA B27 polymorphism in Western India. Tissue Antigens 2002; 60: $98-101$

10. Madhavan R, Parthiban M, Rajendran CP, Chandrasekaran AN, Zake L, Sanjeevi CB. HLA class I and class II association with ankylosing spondylitis in a southern Indian population. Ann N Y Acad Sci 2002; 958:403-7.

11. Davatchi F, Nikbin B, Ala F. Histocompatibility antigens (HLA) inrheumatic diseases in Iran. $J$ Rheumatol Suppl 1977; 3: 36-8.

12. Brautbar C, Porat S, Nelken D, Gabriel KR, Cohen T. HLA B27 and ankylosing spondylitis in the Israeli population. J Rheumatol Suppl 1977; 3: 24-32.

13. Ren EC, Koh WH, Sim D, Boey ML, Wee GB, Chan SH. Possible protective role of HLA-B*2706 for ankylosing spondylitis. Tissue Antigens 1997; 49: 67-9.

14. Chan SH, Satkunananthan K, Wee GB, Srinivan N, Chacha P. HLA-B27 and Chinese ankylosing spondylitis. Singapore Med J 1980; 21: 710-12.

15. Chaiamnuay $P$, Prichanond S, Chiewsilp P. High prevalence of HLA-All in Thai seronegative spondyloarthropathies. J Rheumatol 1983; 10: 790-2.

16. Khan MA. HLA-B27 and its subtypes in world populations. Curr Opin Rheumatol 1995; 7: 263-9.

17. Cipriani A, Rivera S, Hassanhi M, Marquez G, Hernandez R, Villalobos C, et al. HLA-B27 subtypes determination in patients with ankylosing spondylitis from Zulia, Venezuela. Hum Immunol 2003; 64(7): 745-9.

18. Oguz FS, Ocal L, Diler AS, Ozkul H, Asicioglu F,Kasapoglu E, et al. HLA B-27 subtypes in Turkish patients with spondyloarthropathy and healthy controls. Dis Markers 2004; 20(6): 309-12.

19. Gonzalez S, Garcia-Fernandez S, Martinez-Borra J, Blanco-Gelaz MA, Rodrigo L, Sanchez del Rio J, et al. High variability of HLA-B27 alleles in ankylosing spondylitis and related spondyloarthropathies in the population of northern Spain. Hum Immunol 2002; 63(8): 673-6.

20. Varnavidou-Nicolaidou A, Karpasitou K, Georgiou D, Stylianou G, Kokkofitou A, Michalis C, et al. HLAB27 in the Greek Cypriot population: distribution of subtypes in patients with ankylosing spondylitis and other HLA-B27-related diseases. The possible protective role of B*2707. Hum Immunol 2004; 65(12): 1451-4. 
21. Akkoc N, Khan M A. Etiopatogenic role of HLA-B27 alleles in Ankylosing spondylitis. APLAR J Rheumatol 2005; 8: 146-53.

22. Ali EM, Ahmed MU, Alam S, Rahman MH. HLAA, -B and DRB1 allele frequencies in the Bangladeshi population. Tissue Antigen 2008; 72: 115-9.

23. Van der Linden S, Valkenburg HA, Cats A. Evaluation of diagnostic criteria for ankylosingspondylitis. A proposal for modification of the New York criteria. Arthritis Rheum 1984; 27: 361-8.

24. Sarah Lipton, Atul Deodhar. The New ASAS Classification Criteria for Axial and Peripheral Spondyloarthritis. Int J Clin Rheumatol 2012; 7(6): 675-82.

25. Terasaki PI, McClelland JD. Microdroplet assay of human serum cytotoxine. Nature 1964; 204: 998-1000.

26. Ray JG, Hare DB, Kayhoe DE. NIH lymphocytotoxicity technique. In: Manual of tissue typing technique. Maryland: National Institute of Health; 1976; 20-2.

27. Khan MA. A worldwide overview: the epidemiology of HLA-B27 and associated spondyloarthrides. In Calin A, Taurog JD (eds): The Spondyloarthritides. Oxford, University Press, 1998.

28. Ma HJ, Hu FP. Diversity of human leukocyte antigenB27 alleles in Han population of Hunan province, southern China. Tissue Antigens 2006; 68(2): 163-6.

29. Chopra A, Raghunath A, Singh A, Subramanian AR. The pattern of rheumatoid arthritis in the Indian population: a prospective study. Br J Rheumatol 1988; 27: 454-6.

30. Bale UM, Mehta MM, Contractor NM, Bhatia HM, Tilve GH. HLA-B27. Indian J Med Res 1980; 71: 96-100.

31. Zafar N, Khan S, Qadir A, Naqvi A, Rizvi A. HLA frequency in Pakistani population groups. J Pak Med Assoc 1996. Jan; 46(1): 12-3.

32. Gonzalez-Roces S, Alvarez MV, Gonzalez S, Dieye A, Makni H, Woodfield DG, et al. HLA-B27 polymorphism and worldwide susceptibility to ankylosing spondylitis. Tissue Antigens 1997; 49: 116-23.

33. Lopez-Larrea C, Gonzaley S, Martinez-Borra J. The role of HLA B27 polymorphism and molecular mimicry in spondyarthropathy. MoI Med Today 1998; 4: 540-9.

34. Thomas R, Philip J, and Banerjee M. Association of an Extended Haplotype of HLA Class I Alleles and Their Flanking Microsatellites with Spondyloarthropathies in South Indian Patients. Human Immunology 2006; 67: $318-23$.

35. Sonkar GK, Usha. Role of HLA- B27 in diagnosis of seronegative spondyloarthropathies. Indian J Pathol Microbiol 2007; 50: 908-13.

36. Mishra MN, Singal V. Human Leukocyte Antigen B27 in 453 Asian Indian patients with Seronegative Spondyloarthropathy. Iran J. Immunol 2010; 7(4): 252-6. 